Kohl: a Journal for Body and Gender Research

Vol. 2, No. 2 (Winter 2016)

\title{
The Grand Christmas Dinner: Turkey, Rojava, and a Pint of Feminism
}

Y.S.K.Prerana 
There is a de facto autonomous region in the north of Syria: Rojava - whose independence can be attributed to the socialist-feminist army breeding in and out of this conflict zone - laughing, donning bandanas, and shouting "freedom, women, life" at every boulder they face. This army of women is defining postmodern feminism all over again, defying the structures of conflict and capitalism, and proving wrong all the Marxists who shrug off the suffix of "feminist." Independence, here, is being referred to as the ability to live in a democratic space that allows you to act according to non-normative gender roles arising from the prescribed economic and political structures. What makes the independence of Rojava further fascinating is that its democracy is but a consequence of the existence and rise of the women's army, hence primarily implying that there is a group of women out there who are playing against all odds to create a space for, by, and of themselves (as the famous slogan of the free world would go). Even though radical feminists may argue that the concept of a women's army may be playing into male patriarchal values - given how combat has always been defined and seen as "The" male skill by extremists on either end of gender and sexuality based debates, it is fascinating to see the boundaries between patriarchy and liberation being redrawn against the backdrop of conflict. This write-up wishes to explore these boundaries and their symbolisms in the face of an existing feminist militia - that of Rojava.

There are some alternative and regional Kurdish media that have tried to understand these boundaries covertly, often in the scope of art. One such work is a documentary titled Kurdistan: La guerre des filles, ${ }^{1}$ or "Kurdistan: Women at War," wherein viewers can see women with guns and gap within their smiles - perhaps out of apprehension, perhaps out of tight-lipped joy, some sheepishly reading out from the works of Noam Chomsky, some swinging on a piece of log hanging from a tree, some working with the dough in the pantry, all eventually fighting for an "ecological and equal society." Though this may not evidently suggest a discussion on morality and the pragmatics of war, it does open up the viewers to a side of military that is often invisible with regard to a typical men's army - a space which is conducive to the creation of a masculine identity symbolic of traits such as emotional control, overt heterosexual desires, physical fitness, selfdiscipline, and self-reliance. ${ }^{2}$ The women's army of Rojava portrays a side of military that involves itself in activities beyond combat (and hence the practicality of achieving freedom), and holds other members of the society responsible for learning and unlearning patriarchy. And though this aspect is not prevalent and specific to women's armies worldwide, it is one of the central traits displayed by the women's army of Rojava, setting it apart from most military activities that are often consequently suggestive of the crudeness and male hegemonic-ness of their existence. The women's army of Rojava gets involved in the act of active unlearning of patriarchy through the regular camps and workshops held by the army to teach young men the ways and functioning of feminism in everyday life, as the abovementioned documentary reveals. This pulls us back to the question: Is this women's army only a symbol of equality, or is it also about crossing the social structures imposed by internal and external forces in the geopolitical spheres of the Middle Eastern life? When mentioning the geopolitical space, this article wishes to point to the attitudes and conceptions of the white

${ }^{1}$ The entire documentary can be found at: https://www.youtube.com/watch?v=csLMrMOvUJw\&feature=youtu.be. Another documentary on the art and life of Rojava can be found at: https://youtu.be/WEzCqJ40-6U?list=PLxSOYcIG9 QwpFo qiRWffuexL5-znPOi

${ }^{2}$ Hinojosa, R. (2010) "Doing Hegemony: Military, Men, and Constructing a Hegemonic Masculinity." The Journal of Men's Studies 18 (2) p.180. 
world with regard to the Middle East - and how the stereotypes and situated knowledge of the white feminists play an important role in understanding the rise of this feminist space in Rojava.

As Jo Doezema writes in her essay titled "Ouch: Western Feminists' 'wounded attachment' to the 'third world prostitute,"'3 the concept of the "injured body" of the "third world prostitute" is quite central to the functioning of white feminists, and has been so since the Victorian feminists and their colonial perspectives of the Indian women. The essay by Doezema is quite fascinating to follow through, as the entire victimization of women of color by white women is a concept that transcends gender and sexuality to reach the theme of race and geopolitics, and pushes us into visualizing a world that is increasingly being colonialized by the white forces of hegemony. From the U.S. president speaking about the acts of the women's army of Rojava - thus ignoring their contribution to a war started by his country, to the (constant and) recent Western attacks on the bodies of Muslim women in the form of banning burqinis and burqas in France, women of color are increasingly being pushed into the identity of the "helpless women."

The Kurdish Digital newspaper "KurdishQuestion.com" wrote: "US president Barack Obama has said the border between Syria (Rojava) and Turkey will be liberated from jihadist groups. Speaking to journalists following a meeting at the US Department of Defense on the fight against Islamic State in Syria, Iraq and Libya, Obama said, 'ISIL will inevitably be defeated.' Pointing out that the jihadi group was losing territory in Syria and Iraq, Obama said IS was experiencing tough times and had been shown to be not invincible. Obama also added that with US air-support, local forces would take Mosul and Raqqa back and 'liberate the border between Turkey and Syria."' 4 This is when we chime in and start passing the bowl of neoliberal hypocrisy around the dinner table. In the background of influx of nostalgic Obama-appraising articles and internet memes, it is very worrying to realize that the democratic U.S. authorities are waging a proxy war against ISIS - their lovechild - with the Turkish Government (in this context only), even stealing away from the basic acknowledgement of other parties involved in the fight against ISIS.

The female revolutionaries of Rojava are almost untouched by this theft of credit, and continue to believe that self-determination and self-defense are key principles for their liberation from imperialism, capitalism, and patriarchy, as was suggested by the Brighton Kurdish Community at a panel discussion on "Revolution in Rojava and Beyond." This new socio-economic system they aim to set into motion will also offer the possibility for transformative peace and freedom in the larger context of the Middle Eastern crisis, they expounded further, while introducing the science of "Jineology," which primarily states that without the freedom of women within society and without a real consciousness surrounding women, no society can call itself free and liberated. Before you shake your head and discard this as just another "pretending-to-change-the-world-bythrowing-in-big-words-and-theories," it might be useful to acknowledge that women make up to $50 \%$ of the fighting forces and over $40 \%$ of elected representatives (even within political parties in Syria and Turkish Kurdistan) in Rojava; and that is just the allure of the numbers. Since the inception of the People's Defense

\footnotetext{
${ }^{3}$ Doezema, J. (2001) "Ouch: Western Feminists' 'Wounded Attachment' to the 'Third World Prostitute."' Feminist Review 67 pp.16-38

${ }^{4}$ http://kurdishquestion.com/article/3337-obama-rojava-border-to-be-liberated
} 
Unit (YPG) in Rojava in 2006 to fight the ISIS, the YPG has now grown into having a separate unit of force (YPJ), comprised only of women. It is undeniable that the YPJ is still a Kurdish military force under the Kurdish Political Party (PYD). Thus, the hierarchy of being under a self-prescribed male leader encompasses the women's army, but the army must also be lauded for its efforts to make the military space more intersectional and liberating in terms of ethnicities and genders. A glimpse of it can be seen in the fact that Rojava itself is a polyethnic region with three different cantons; however, the bottom-up approach of governance of the YPJ coupled with the increasingly liberated society in terms of gender roles have projected Rojava as an alternative to the current capitalist regimes that are evidently failing in those terms in most parts of the world. Though a poster-place that substitutes capitalism with a socially extricated setup, the fight of both the women's army and Rojava has not been and is not as easy as this article makes it seem.

In his preface to Revolution in Rojava, David Graeber writes: “...even in Rojava, there is opposition, even if much of it takes covert form. 'No man dares challenge the principle of gender equality in public,' one organizer for Yekitiya Star, the Rojava's women's union, told me. 'But physical attacks on women nearly doubled in the first years of revolution.' This was one of the main reason for creating women's courts, women's justice committees that regularly increased the penalties of men found guilty of such assaults by the neighborhood 'peace and consensus' committee" (p.xv). ${ }^{5}$ He goes on to add one of the simplest, yet most resonating sentence for us activists of the $21^{\text {st }}$ century: "I point this out only to emphasize that no real, revolutionary change is won without a struggle, and much of the internal, social struggle is invisible to the outside eye" ( $p$. xii). The outside eye, for me, would translate as the "white" portion (sclera) of the human eye: said to have developed for the benefit of nonverbal communication, bigger than most sclera of the animal kingdom, it is however not part of the eye that actually "senses/sees" objects. I say this in reference to the "white" world, which has grown more ornamental than genuine in conflict zones, more prominent in terms of authority, and yet depicts a reality that is self-righteous and blurry. Right now, the outside world - the white world - is troubled by the Great U.S. Elections and the repercussions of having a U.S. President who wants to repel ObamaCare and deny Climate change - not to suggest that the consequences of this election would be limited to the functioning of the white world, but rather to imply the importance the American elections have gained through systematic hegemony over the decades. A couple of weeks ago, the white world was bothered by how "men are not babies" for opting out of the famous male birth control study - even though female birth control was applauded as a consequence of medical advancement the first time it was introduced, and became the convention of protected sexual intimacies in heterosexual relationships. This brings me back to the question, again. And again: Is this women's army only a symbol of equality, or is it also about crossing the social structures imposed by internal and external forces in the geopolitical spheres on/of the Middle Eastern life?

If learning about this women's army does not make us stop, breathe, and maybe alter our Christmas plans a bit (to discard Turkey off the platter and include some readings and revolts), I guess our privileges are to be

${ }^{5}$ Graeber, D. (2016) "Foreword." Revolution in Rojava: Democratic Autonomy and Women's Liberation in Syrian Kurdistan. Ed. by Michael Knapp, Anja Flach and Ercan Ayboga, PlutoPress. 
Kohl 2.2

158 blamed - and I am saying this as a brown Indian woman studying at a British University, and spending 150 pounds a week on her rent. 